\title{
В0ПРОСЫ СТОМАТОЛОГИИ
}

\section{DENTAL HEALTH}

\section{СПОСОБ ПРЕПАРИРОВАНИЯ «ПО ОСИ» ЗУБОВ, СЛУЖАЩИХ ОПОРОЙ ПОД ПРОТЯЖЕННЫЕ ОРТОПЕДИЧЕСКИЕ КОНСТРУКЩИИ}

\author{
Д.И. Дмитриев \\ Новокуйбышевская стоматологическая поликлиника, Новокуйбышевск
}

\begin{abstract}
Резюме. Часто встречающейся ошибкой врача стоматолога-ортопеда при проведении одонтопрепарирования зубов является несоблюдение параметров допустимой конвергенции осевых стенок зубов [1]. Анализ литературы позволяет заключить, что при конусности стенок зуба в 15 градусов ретенция коронок составляет 70 \% [2]. Целью работы явилась разработка усовершенствованного способа соосного одонтопрепарирования зубов. В данной статье приведено описание методики одонтопрепарирования зубов, являющихся опорой под несъемные ортопедические конструкции протяженного характера. Суть способа заключается в создании ложа на опорных зубах с помощью тонкого фиссурного бора. Процесс соосного препарирования опорных зубов в авторской методике состоит из нескольких этапов, что дает возможность осуществлять контроль за точностью препарирования и качественно снизить вероятность чрезмерного сошлифовывания тканей зуба.
\end{abstract}

Ключевые слова: одонтопрепарирование зубов, конвергенция, ретенционное препарирование.

Для цитирования: Дмитриев Д.И. Способ препарирования «по оси» зубов, служащих опорой под протяженные ортопедические конструкции. Вестник медицинского института «РЕАВИЗ». Реабилитация, Врач и Здоровье. 2021;4(52):135-138. https://doi.org/10.20340/vmi-rvz.2021.4. DENT.1

\section{METHOD OF PREPARATION "ALONG THE AXIS" OF TEETH THAT SERVE AS A SUPPORT FOR EXTENDED 0RTHOPEDIC STRUCTURES}

\section{D.I. Dmitriev}

Novokuibyshevsk Dental Clinic, Novokuybyshevsk

\begin{abstract}
A common mistake of an orthopedic dentist when carrying out odontopreparation of teeth is nonobservance of the parameters of the permissible convergence of the axial walls of the teeth [1]. Analysis of the literature allows us to conclude that with the taper of the tooth walls at 15 degrees, the retention of the crowns is $70 \%$ [2]. The aim of this work was the development of an improved method for coaxial odontopreparation of teeth. This article describes the method of odontopedication of teeth, which are a support for fixed orthopedic structures of an extended nature. The essence of the method is to create a bed on the abutment teeth using a thin fissure bur. The process of coaxial preparation of abutment teeth in the author's technique consists of several stages, which makes it possible to control the preparation accuracy and qualitatively reduce the likelihood of excessive grinding of tooth tissues.
\end{abstract}


Key words: odontopreparation of teeth, convergence, retention preparation.

Cite as: Dmitriev D.I. Method of preparation "along the axis" of teeth that serve as a support for extended orthopedic structures. Bulletin of the Medical Institute REAVIZ. Rehabilitation, Doctor and Health. 2021;4(52):135138. https://doi.org/10.20340/vmi-rvz.2021.4. DENT.1

\section{Введение}

Часто встречающейся ошибкой врача стоматолога-ортопеда при проведении одонтопрепарирования зубов является несоблюдение параметров допустимой конвергенции осевых стенок зубов [1]. Анализ литературы позволяет заключить, что при конусности стенок зуба в 15 градусов ретенция коронок составляет $70 \%$ [2]. Наиболее сложным в техническом и мануальном исполнении является одонтопрепарирование под многоопорные и мостовидные ортопедические конструкции, нежели под одиночные коронки. Основной проблемой является соблюдение соосности препарируемых культей зубов. Обычно, перед этапом проведения одонтопрепарирования, с помощью специального маркера на опорные зубы наносятся линии, служащие ориентиром для врача при одонтопрепарировании [3, 4]. Существенным недостатком такого способа является то, что маркировочные линии наносятся только на вестибулярную поверхность препарируемого зуба, а контроль их параллельности друг другу осуществляется «на глаз» и во многом зависит от опытности врача-стоматолога. K тому же, плохая визуализация наносимых линий вследствии их преждевременного смывания является значительным минусом этого метода.

Ряд авторов рекомендуют использование внутриротовых параллелометров [5, 6]. Однако сложность установки в полость рта, а также ограниченное пространство для манипуляций при одонтопрепарировании привело к довольно низкой популярности среди стоматологов-ортопедов.

Целью данной статьи явилась разработка усовершенствованного способа соосного одонтопрепарирования зубов.

\section{Материалы и методы}

Предлагаемый автором способ одонтопрепарирования имеет два существенных преимущества: 1) применение внутриротового зеркала для контроля качества нанесения параллельных маркировочных линий; 2) маркировочные линии наносятся не пишущими принадлежностями, а пропиливаются очень тонким пиковидным стоматологическим бором (рис. 1). Получаемые линии имеют вид отчетливой, ровной, тонкой полоски, несмываемой и легко визуализируемой. Данные линии наносятся не только на вестибулярную поверхность, но и язычную и жевательную поверхности опорных зубов. Данная особенность позволяет контролировать качество конусности препарирования опорных зубов по всему периметру культи зуба.

Методика предлагаемого способа состоит в следующем. После сошлифовывания по высоте на опорные зубы путем использования тонкого пиковидного бора (859/010) наносятся маркировочные линии строго параллельные друг другу. Первоначально маркировочная линия наносится на вестибулярную поверхность контрольного зуба (контрольный зуб - тот, относительно которого задается параллельность одонтопрепарирования для окружающих культей зубов). Следом на вестибулярные поверхности остальных культей зубов, которые будут задействованы в планируемой ортопедической конструкции, последовательно наносятся маркировочные линии. Для осуществления контроля соосности линий используют внутриротовое зеркало. После нанесения линий на вестибулярную поверхность культи зуба приступают к маркировке жевательной и язычной поверхностей. Таким образом, при окончании нанесения маркировочных линий на зубе образуется три линии (язычная, жевательная, вестибулярная), соосные между собой. 


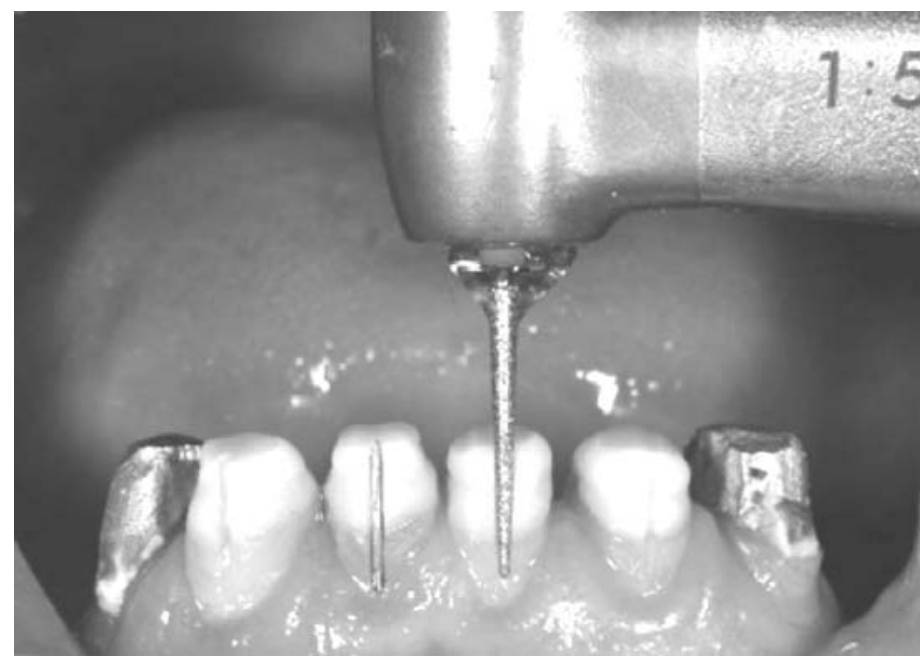

Рис. 1. Нанесение маркировочных линий пиковидным бором

Fig. 1. Application of marking lines with peak-shaped boron

На следующем этапе осуществляют сепарацию таким же пиковидным бором. Расширение межзубного пространства проводят путем последовательного использования боров с нарастающим диаметром (от 1,2 мм 886/012 до 1,4 мм 886/014). Сошлифовывание твердых тканей зуба на вестибулярной поверхности проводят до полной идентичности поверхности препарируемого зуба и дна маркировочной линии. Стоит отметить, что ортопедическое сошлифовывание твердых тканей оральной поверхности фронтальной группы зубов требует создания так называемых зон резистентности, необходимых для обеспечения адекватной ретенции ортопедической конструкции в дальнейшем [7, 8].
В завершении врач проверяет качество проведенного одонтопрепарирования при помощи внутриротового зеркала. Выявленные недостатки - острые углы, шероховатости - устраняются. Для финишной подготовки культи зуба используются различные мелкозернистые боры и полировочные диски.

\section{Выводы}

Таким образом, предлагаемый автором способ одонтопрепарирования зубов под ортопедические конструкции позволяет осуществлять контроль за точностью препарирования и качественно снизить вероятность чрезмерного сошлифовывания тканей зуба.

\section{Литература/References}

1 Seymour KG, Samarawickrama DY, Lynch EJ. Metal ceramic crowns - a review of tooth preparation. Eur J Prosthodont Restor Dent. 2009;7:79-84.

2 Jorgensen KD. The relationship between retention and convergence angle in cemented veneer crowns. Acta Odonto/Scand. 1955;13:35-40.

3 Massironi D, Paschetta R, Romeo D. Accuracy and aesthetics. Clinical and dental engineering stages of dental prosthesis. M.: ABC; 2018.

4 Fradeani M. Analysis of aesthetics. Systematic approach to orthopedic treat-ment. Vol. 1. Aesthetic rehabilitation with non-removable dental prostheses. M.: The ABC of the Dentist; 2017.

5 Nelson JA, Vlazny AL. Axial wall parallel development method. Quintessence Int Dent Dig. 2015;14(7):719-723.

6 Vitsentzos SI. A new device to directly examine parallelism of abutment teeth. J Prosthet Dent. 2009;61(5):531-534.

7 Shillingburg HT, Jacobi R, Brackett SE. Fundamentals of tooth preparations: for cast metal and porcelain restorations. Chicago: Quintessence Publishing Co.; 2017.

8 Semenza M. Tecniche di preparazione. Teamwork Media. 2018;98. 
Конфликт интересов. Авторы заявляют об отсутствии конфликта интересов.

Competing interests. The authors declare no competing interests.

Финансирование. Исследование проводилось без спонсорской поддержки.

Funding. This research received no external funding.

\section{Авторская справка}

Дмитриев Дмитрий Игоревич

врач-стоматолог-ортопед, главный врач, Новокуйбышевская стоматологическая поликлиника, Новокуйбышевск, Россия

e-mail: s1131149@yandex.ru

ORCID 0000-0001-5522-0420 